\title{
Response of Different Levels of Zinc and Molybdenum on Yield Attribute and Economics of Blackgram (Vigna mungo L.) under Agro-climatic East Uttar Pradesh, India
}

\author{
Chhatrapati Mahilane*, Vikram Singh and Raisen Pal
}

Department of Agronomy, Naini Agricultural Institute, Sam Higginbottom University of Agriculture, Technology \& Sciences Allahabad - 211007 Uttar Pradesh (India)

*Corresponding author

\begin{abstract}
A B S T R A C T
A field experiment was conducted during the Zaid season 2016 at the Crop Research farm of Agronomy, Naini Agricultural Institute, SHUATS, Allahabad (U.P.) to Field evaluation

Keywords

Blackgram, Zinc and Molybdenum

Article Info

Accepted:

24 November 2018

Available Online:

10 December 2018 of blackgram (Vigna mungo L.) under Agro-climatic zone of Allahabad. The experiment was conducted to find out the effect of different levels of zinc and molybdenum on growth and yield of blackgram (Vigna mungo L.) laid out in RBD with 9 treatment and 3 replications. The treatment consisted of three levels of zinc $\left(0,5\right.$ and $\left.7.5 \mathrm{~kg} \mathrm{ha}^{-1}\right)$, three levels of molybdenum $\left(0,0.5\right.$ and $\left.1.0 \mathrm{~kg} \mathrm{ha}^{-1}\right)$. results revealed that the maximum number of nodules plant ${ }^{-1}(5.87,16.67,24.33,10.93 \mathrm{~cm}$, at 15 DAS, 30 DAS, 45 DAS and 60 DAS respectively), maximum Pods plant ${ }^{-1}$ was recorded as 20.40, maximum Relative growth rate $\left(\mathrm{g} \mathrm{g}^{-1} \mathrm{day}^{-1}\right)(0.09$, and $0.17 \mathrm{~cm}$, at 45 DAS and 60 DAS respectively), maximum Grain yield $\mathrm{t} \mathrm{ha}^{-1}$ was recorded as 1.01, Straw yield $\mathrm{t} \mathrm{ha}^{-1}$ was recorded as 4.14 and maximum benefit cast ratio was recorded as 4.66 . However significantly the highest nodules plant ${ }^{-1}$, Pods plant ${ }^{-1}$, Relative growth rate $\left(\mathrm{g} \mathrm{g}^{-1} \mathrm{day}^{-1}\right)$, Grain yield $\mathrm{tha}^{-1}$ and Straw yield $\mathrm{t} \mathrm{ha}^{-1}$ was found in $\left(\mathrm{T}_{9}\right)$ R.D.F+ Zinc7.5 kg ha ${ }^{-1}+$ Molybdenum1.0 kg ha $\mathrm{kg}^{-1}$ and highest benefit ratio was found in $\left(\mathrm{T}_{4}\right)$ R.D.F + Zinc $5 \mathrm{~kg} \mathrm{ha}^{-1}+$ Molybdenum $00 \mathrm{~kg} \mathrm{ha}^{-1}$.
\end{abstract}

\section{Introduction}

Blackgram crop grown in many parts of India. This crop is grown in the cropping systems as a mixed crop, catch crop, sequential crop besides growing as sole crop under residual moisture conditions after the harvest of other summer crops under semi- irrigated and dry land conditions. Its seeds are highly nutritious with protein $(25-26 \%)$, carbohydrates $(60 \%)$, fat $(1.5 \%)$, minerals, amino acids and vitamins. Seed are used in the preparation of many popular dishes. it is one of the most important components in the preparation of famous south Indian dishes, e.g., dosa, idli, vada etc, besides, it adds about $42 \mathrm{~kg}$ nitrogen per hectare in soil. (Source: Department of Agriculture, Govt. of Sikkim). In India, Blackgram is very popularly grown in Andhra Pradesh, Bihar, Madhya Pradesh, Maharashtra, Uttar Pradesh and West Bengal, Punjab, Haryana and Karnataka (Singh, 2010). 
Zinc is most the daily $\mathrm{Zn}$ requirement of humans, the amounts of $\mathrm{Zn}$ in the seed need to exceed the optimum level for the crop itself (Grusak and Cakmak, 2005). This implies an urgent need to find new agricultural technologies to obtain sufficient yield of good quality crops, also with respect to globally limited natural resources such as fertilizer and the enormous loss of fertile soils low availability of $\mathrm{Zn}$ in soils is one of the widest ranging a biotic stresses in the world agriculture. Black gram and green gram in an important pulse crop grown throughout India where micronutrients play in important role in its production. (Cordell et al., 2009; Adesemoyes et al., 2009).

Molybdenum is one of the most recognized micronutrient element considered to be essential for the growth of plants and improving the crop yield and quality (Tahir et al., 2014). As the constituent of nitrate reductase and nitrogenase enzymes, molybdenum directly influences nitrogen assimilation and its fixation in pulse crop (Biswas et al., 2009). Yield level of major pulses. Also, the perceptions of farmers about their adaptation strategies in the changing climatic regime were ascertained (Dubey et al., 2006).

\section{Materials and Methods}

This experiment was conducted in the year 2016 during Zaid season at Crop Research Farm (CRF), Naini Agricultural Institute, Department of Agronomy, Sam Higginbottom University of Agriculture, Technology and Sciences, Allahabad. The geographical coordinates of Allahabad are $25^{0} 57^{0} \mathrm{~N}$ latitude and $87^{\circ} 19^{\circ} \mathrm{E}$ longitude and an altitude of 98 $\mathrm{m}$ above mean sea level. The area is situated on the south of the Allahabad (U.P.) on the side of the Yamuna River at Rewa road at a distance of about $5.0 \mathrm{~km}$ away from Allahabad city. All the facilities required for crop cultivation are available.
The soil is experimental plot was sandy loam in texture having $\mathrm{pH}$ of 7.60 with low level of organic carbon $00.34 \%$, available medium level of $\mathrm{P}\left(13.5 \mathrm{~kg} \mathrm{ha}^{-1}\right)$ and higher level of $\mathrm{K}$ $\left(336 \mathrm{~kg} \mathrm{ha}^{-1}\right)$. The experiment was laid out randomized block design, comprising of sixteen treatment combinations each replicated thrice.

The treatments consisted of three Zinc levels (0, 5 and $7.5 \mathrm{~kg} \mathrm{ha}^{-1}$ ) and three levels of molybdenum $\left(0,0.5\right.$ and $\left.1.0 \mathrm{~kg} \mathrm{ha}^{-1}\right)$ with recommended dose 20:60:20 NPK kg ha-1.

Total nine treatment combinations viz., $\mathrm{T}_{1}$ : R.D.F + Zinc $00 \mathrm{~kg} \mathrm{ha}^{-1}+$ Molybdenum $00 \mathrm{~kg}$ $\mathrm{ha}^{-1}, \quad \mathrm{~T}_{2}$ : R.D.F + Zinc $00 \mathrm{~kg} \mathrm{ha}^{-1}+$ Molybdenum $0.5 \mathrm{~kg} \mathrm{ha}^{-1}, \mathrm{~T}_{3}$ : R.D.F + Zinc 00 $\mathrm{kg} \mathrm{ha}^{-1}+$ Molybdenum $1.0 \mathrm{~kg} \mathrm{ha}^{-1}, \mathrm{~T}_{4}$ : R.D.F + Zinc $5 \mathrm{~kg} \mathrm{ha}^{-1}+$ Molybdenum $00 \mathrm{~kg} \mathrm{ha}^{-1}$, $\mathrm{T}_{5}$ : R.D.F+ Zinc $5 \mathrm{~kg}$ ha-1 + Molybdenum 0.5 $\mathrm{kg} \mathrm{ha}{ }^{-1}, \mathrm{~T}_{6}$ : R.D.F + Zinc $5 \mathrm{~kg} \mathrm{ha}^{-1}+$ Molybdenum $1.0 \mathrm{~kg} \mathrm{ha}^{-1}, \mathrm{~T}_{7}$ : R.D.F+ Zinc 7.5 $\mathrm{kg} \mathrm{ha}^{-1}+$ Molybdenum $00 \mathrm{~kg} \mathrm{ha}^{-1}, \mathrm{~T}_{8}$ : R.D.F+ Zinc $7.5 \mathrm{~kg} \mathrm{ha}^{-1}+$ Molybdenum $0.5 \mathrm{~kg} \mathrm{ha}^{-1}$, $\mathrm{T}_{9}$ : R.D.F+Zinc $7.5 \mathrm{~kg} \mathrm{ha}^{-1}+$ Molybdenum 1.0 $\mathrm{kg} \mathrm{ha}^{-1}$. Five plants were taken from each plot to measure the plant height and yield attributes.

\section{Statistical analysis}

The value of table ' $\mathrm{F}$ at 5\% level significance, where the treatment difference between were found significant the value of $\mathrm{CD}$ and $\mathrm{CV} \%$ were also worked out to compare the treatment mean (Snedecor and Cochran, 1967). At initial stage select random five plants from net plot area for further recording observations.

\section{Results and Discussion}

Results revealed that the maximum number of nodules plant ${ }^{-1}(5.87,16.67,24.33,10.93 \mathrm{~cm}$, at 15 DAS, 30 DAS, 45 DAS and 60 DAS 
respectively), maximum Pods plant ${ }^{-1}$ was recorded as 20.40, maximum Relative growth rate $\left(\mathrm{g} \mathrm{g}^{-1}\right.$ day $\left.^{-1}\right)(0.09$, and $0.17 \mathrm{~cm}$, at 45 DAS and 60 DAS respectively), maximum Grain yield $\mathrm{t} \mathrm{ha}^{-1}$ was recorded as 1.01 , Straw yield $\mathrm{t}$ $\mathrm{ha}^{-1}$ was recorded as 4.14 and maximum benefit cast ratio was recorded as 4.66 .

However significantly the highest nodules plant $^{-1}$, Pods plant ${ }^{-1}$, Relative growth rate $\left(\mathrm{g} \mathrm{g}^{-1} \mathrm{day}^{-1}\right)$, Grain yield $\mathrm{t} \mathrm{ha}^{-1}$ and Straw yield $\mathrm{t} \mathrm{ha}^{-1}$ was found in $\left(\mathrm{T}_{9}\right)$ R.D.F+ Zinc7.5 kg $\mathrm{ha}^{-1}+$ Molybdenum1.0 kg ha ${ }^{-1}$ and highest benefit ratio was found in $\left(\mathrm{T}_{4}\right)$ R.D.F + Zinc 5 $\mathrm{kg} \mathrm{ha}^{-1}+$ Molybdenum $00 \mathrm{~kg} \mathrm{ha}^{-1}$.

The probable reason for dry matter accumulation plant ${ }^{-1}$ number of nodules plant $^{-1}$, pod RGR $\left(\mathrm{g} \mathrm{g}^{-1}\right.$ day $\left.^{-1}\right)$, grain yield $\mathrm{tha}^{-1}$ and straw yield $t \mathrm{ha}^{-1}$ may be due to beneficial effect of zinc and molybdenum (Table 1-3).

Table.1 Effect of different levels of zinc and molybdenum on Number of nodules plant-1 and Relative growth rate (g g-1day-1) of blackgram (Vigna mungo L.)

\begin{tabular}{|c|c|c|c|c|c|c|}
\hline \multirow[t]{2}{*}{ Treatment combinations } & \multicolumn{4}{|c|}{ Number of nodules plant ${ }^{-1}$} & \multicolumn{2}{|c|}{$\begin{array}{l}\text { Relative growth } \\
\text { rate }\left(\mathrm{g} \mathrm{g}^{-1} \text { day }^{-1}\right)\end{array}$} \\
\hline & 15 DAS & 30 DAS & 45 DAS & 60 DAS & 45 DAS & 60 DAS \\
\hline $\begin{array}{l}\text { T }_{1} \text { : R.D.F + Zinc } 00 \mathrm{~kg} \mathrm{ha}^{-1}+ \\
\text { Molybdenum 00kg ha }\end{array}$ & 4.07 & 9.73 & 20.93 & 9.13 & 0.06 & 0.17 \\
\hline $\begin{array}{l}\mathrm{T}_{2}: \text { R.D.F + Zinc 00 kg ha' } \\
\text { Molybdenum } 0.5 \mathrm{~kg} \mathrm{ha}^{-1}\end{array}$ & 5.07 & 10.53 & 21.87 & 9.50 & 0.08 & 0.16 \\
\hline $\begin{array}{l}\text { T}_{3}: \text { R.D.F + Zinc } 00 \mathrm{~kg} \mathrm{ha}^{-1}+ \\
\text { Molybdenum } 1.0 \mathrm{~kg} \mathrm{ha}^{-1}\end{array}$ & 4.80 & 11.87 & 23.53 & 10.13 & 0.07 & 0.17 \\
\hline $\begin{array}{l}\text { T4: R.D.F + Zinc } 5 \mathrm{~kg} \mathrm{ha}^{-1}+ \\
\text { Molybdenum } 00 \mathrm{~kg} \mathrm{ha}^{-1}\end{array}$ & 5.27 & 12.40 & 21.07 & 9.53 & 0.06 & 0.16 \\
\hline $\begin{array}{l}\mathrm{T}_{5:} \text { R.D.F+ Zinc } 5 \mathrm{~kg} \mathrm{ha}^{-1}+ \\
\text { Molybdenum } 0.5 \mathrm{~kg} \mathrm{ha}^{-1}\end{array}$ & 5.33 & 13.53 & 22.53 & 9.33 & 0.07 & 0.16 \\
\hline $\begin{array}{l}\text { T6: R.D.F + Zinc } 5 \mathrm{~kg} \mathrm{ha}^{-1}+ \\
\text { Molybdenum } 1.0 \mathrm{~kg} \mathrm{ha}^{-1}\end{array}$ & 5.47 & 14.20 & 24.13 & 10.13 & 0.08 & 0.17 \\
\hline $\begin{array}{l}\text { T7: R.D.F+ Zinc } 7.5 \mathrm{~kg} \mathrm{ha}^{-1}+ \\
\text { Molybdenum } 00 \mathrm{~kg} \mathrm{ha}^{-1}\end{array}$ & 5.13 & 14.93 & 21.47 & 9.60 & 0.06 & 0.16 \\
\hline $\begin{array}{l}\text { T8: R.D.F+ Zinc } 7.5 \mathrm{~kg} \mathrm{ha}^{-1}+ \\
\text { Molybdenum } 0.5 \mathrm{~kg} \mathrm{ha}^{-1}\end{array}$ & 5.53 & 15.73 & 23.07 & 10.07 & 0.07 & 0.17 \\
\hline $\begin{array}{l}\text { T9: R.D.F+ Zinc7.5 } \mathrm{kg} \mathrm{ha}^{-1}+ \\
\text { Molybdenum } 1.0 \mathrm{~kg} \mathrm{ha}^{-1}\end{array}$ & 5.87 & 16.67 & 24.33 & 10.93 & 0.09 & 0.17 \\
\hline F test & S & S & S & S & S & S \\
\hline SEd(_+) & 0.11 & 0.13 & 0.10 & 0.15 & 0.001 & 0.001 \\
\hline $\mathrm{CD}(\mathrm{P}=0.05)$ & 0.24 & 0.28 & 0.20 & 0.32 & 0.001 & 0.001 \\
\hline
\end{tabular}


Table.2 Effect of different levels of zinc and molybdenum on yield attributes (Pods plant-1, Grain yield tha-, Straw yield t ha-1) of blackgram (Vigna mungo L.)

\begin{tabular}{|c|c|c|c|}
\hline Treatment combinations & Pods plant $^{-1}$ & $\begin{array}{l}\text { Grain yield t } \\
\text { ha }^{-1}\end{array}$ & $\begin{array}{l}\text { Straw yield } t \\
\text { ha }^{-1}\end{array}$ \\
\hline $\begin{array}{l}\text { T }_{1} \text { : R.D.F + Zinc } 00 \mathrm{~kg} \mathrm{ha}^{-1}+ \\
\text { Molybdenum 00kg ha }\end{array}$ & 17.00 & 1.01 & 3.71 \\
\hline $\begin{array}{l}\mathrm{T}_{2}: \text { R.D.F + Zinc } 00 \mathrm{~kg} \mathrm{ha}^{-1}+ \\
\text { Molybdenum } 0.5 \mathrm{~kg} \mathrm{ha}^{-1}\end{array}$ & 17.27 & 1.10 & 3.80 \\
\hline $\begin{array}{l}\text { T }_{3}: \text { R.D.F + Zinc } 00 \mathrm{~kg} \mathrm{ha}^{-1}+ \\
\text { Molybdenum } 1.0 \mathrm{~kg} \mathrm{ha}^{-1}\end{array}$ & 17.93 & 1.15 & 3.81 \\
\hline $\begin{array}{l}\text { T4: R.D.F + Zinc } 5 \mathrm{~kg} \mathrm{ha}^{-1}+ \\
\text { Molybdenum } 00 \mathrm{~kg} \mathrm{ha}^{-1}\end{array}$ & 17.73 & 1.08 & 3.71 \\
\hline $\begin{array}{l}\text { T5: R.D.F + Zinc } 5 \mathrm{~kg} \mathrm{ha}^{-1}+\text { Molybdenum } \\
0.5 \mathrm{~kg} \mathrm{ha}^{-1}\end{array}$ & 18.33 & 1.11 & 3.96 \\
\hline $\begin{array}{l}\text { T6: R.D.F + Zinc } 5 \mathrm{~kg} \mathrm{ha}^{-1}+ \\
\text { Molybdenum 1.0kg ha-1 }\end{array}$ & 19.33 & 1.17 & 4.14 \\
\hline $\begin{array}{l}\text { T } 7 \text { R.D.F+ Zinc } 7.5 \mathrm{~kg} \mathrm{ha}^{-1}+ \\
\text { Molybdenum } 00 \mathrm{~kg} \mathrm{ha}^{-1} \\
\end{array}$ & 18.60 & 1.09 & 3.87 \\
\hline $\begin{array}{l}\text { T: R.D.F + Zinc } 7.5 \mathrm{~kg} \mathrm{ha}^{-1}+ \\
\text { Molybdenum } 0.5 \mathrm{~kg} \mathrm{ha}^{-1}\end{array}$ & 19.13 & 1.13 & 3.84 \\
\hline $\begin{array}{l}\text { T9: R.D.F+ Zinc7.5 kg ha } \\
\text { Molybdenum } 1.0 \mathrm{~kg} \mathrm{ha}^{-1}\end{array}$ & 20.40 & 1.18 & 3.84 \\
\hline F test & $\mathbf{S}$ & S & S \\
\hline SEd(_+) & 0.09 & 0.003 & 0.01 \\
\hline $\mathrm{CD}(\mathrm{P}=0.05)$ & 0.21 & 0.010 & 0.03 \\
\hline
\end{tabular}

Table.3 Evaluation of different Benefit cost Ratio (C:B) of different Treatment Combination of Blackgram (Vigna mungo L.)

\begin{tabular}{|l|l|l|l|l|l|l|}
\hline Treatment & $\begin{array}{l}\text { Grain } \\
\text { yield } \\
\left(\text { t.ha }^{-1}\right)\end{array}$ & $\begin{array}{l}\text { Straw } \\
\text { yield } \\
\left(\text { t.ha }^{-1}\right)\end{array}$ & $\begin{array}{l}\text { Gross } \\
\text { return } \\
\text { (Rs.) }\end{array}$ & $\begin{array}{l}\text { Total Cost of } \\
\text { cultivation } \\
(\text { Rs.) }\end{array}$ & $\begin{array}{l}\text { Net return } \\
\text { (Rs.) }\end{array}$ & BCR \\
\hline $\mathrm{T}_{1}$ & 1.01 & 3.71 & 101515.00 & 22674.00 & 78841.00 & 4.48 \\
\hline $\mathrm{T}_{2}$ & 1.10 & 3.80 & 110200.00 & 31074.00 & 79126.00 & 3.54 \\
\hline $\mathrm{T}_{3}$ & 1.14 & 3.81 & 114015.00 & 39474.00 & 74541.00 & 2.89 \\
\hline $\mathrm{T}_{4}$ & 1.08 & 3.71 & 108165.00 & 23174.00 & 84991.00 & 4.66 \\
\hline $\mathrm{T}_{5}$ & 1.11 & 3.96 & 111390.00 & 31574.00 & 79816.00 & 3.53 \\
\hline $\mathrm{T}_{6}$ & 1.17 & 4.14 & 117360.00 & 39974.00 & 77386.00 & 2.93 \\
\hline $\mathrm{T}_{7}$ & 1.09 & 3.87 & 109355.00 & 23424.00 & 85931.00 & 4.67 \\
\hline $\mathrm{T}_{8}$ & 1.14 & 3.84 & 114060.00 & 31824.00 & 82236.00 & 3.58 \\
\hline $\mathrm{T}_{9}$ & 1.18 & 3.84 & 117860.00 & 40224.00 & 77636.00 & 2.93 \\
\hline
\end{tabular}


However the essential role of zinc has been established as a component of several enzymes concerned with carbohydrate and nitrogen metabolism, in addition to its involvement directly or indirectly in regulating the various physiological processes of plants. Similar results were reported by Sharma et al., (2010) significant difference in dry matter per plant was recorded with $15 \mathrm{~kg}$ Zn/ha (Ullah et al., 2007).

\section{References}

Awoni Alben T, Singh A. K., Kumar Manoj, Bordoloi L. J.. (2012). Effect of Phosphorus, Molybdenum and Cobalt Nutrition on Yield and Quality of Mungbeen (Vigna radiata L) in Acidic Soil in North East India Indian Journal of Hill Faming 25 (2): 22-26.

Baudh, A.K., and Prasad, G., (2012) Interaction effect of different dose of sulphur and zinc with nitrogen, phosphorus and organic manure on growth and productivity of mustard (Brassica compestris L.) Indian Jon. Sci. Res. 3 (1); 141-144.

Bhuiyan M.M.H, M.M Rahman, F Afroze, G.N.C Sutradhar, and M.S.I. Bhuiyan. (2008). Effect of Phosphorus, Molybdenum and Rhizobium inoculation on growth and Nodulation of Mungbean. J. Soil. Nature. 2 (2):2530.

Biswas P. K., Bhowmick M. K. and Bhattacharyya Anjan. (2009). Effect of Molybdenum and Seed inoculation on nodulation, growth and yield in urdbean (Vigna mungo L.) Journal of crop and weed 5 (1):141-144.

Dubey, S. C. and Singh, B., 2006. Influence of sowing time on development of cercospora leaf spot and yellow mosaic diseases of urdbean (Vigna mungo). Indian Journal of Agricultural Sciences 76 (12): 766-9.
GOI. (2015). Agriculture Statistics at a glance: published by Ministry of Agriculture, Govt. of India. http://www.nabard.org.in.

Grusak, M.A and Cakmak, I. (2005) Methods to improve the crop delivery of minerals to humans and livestock. In. Plant Nutritional Genomics. CRC Press, Boca Raton, 265-286.

Karpagam J. and Rajesh. N (2014). Molybdenum application for enhancing growth, Yield and Soil Health on green gram (Vigna radiata L.) AmericanEurasian J. Agric. \& Environ. Sci., 14 (12): 1378-1381.

Krishna. (1995) Effect of sulphur and zinc application on yield, $\mathrm{S}$ and $\mathrm{Zn}$ uptake and protein content of mung Legume Research 18(2): 89-92.

Meenu (2010). Effect of zinc, molybdenum, urea and their interactions on the growth and yield of urdbean (Vigna mungo L.) Hepper. Thesis (Botany), Chaudhary Charan Singh University, Meerut, Indian. J. Pulse Res., 18(2):214-216.

Perumal, R., Vijayarengan, P., Balamurugan, S and Thiyagarajan, G. (2012) Effect of zinc on growth, dry matter yield and nutrient content of Vigna radiata (1.) Wilczek International Journal of Recent Scientific Research 3 (8), 687 -692.

Ram Surendra and T.P.S. Katiyar, (2013). Effect of sulphur and zinc on seed yield and protein content of summer mungbean under arid climatic International Journal of Science and Nature 4 (3): 563-566

Sharma, V and Abraham, T. (2010) Response Of Blackgram (Phaseolus mungo) To Nitrogen, Zinc and Farm Yard Manure Legume Res. 33, (4) 295-298.

Singh Kumar Sushil, Singh Satendrapal and Chand Gopi. (2014). Effect of phosphorus, sulphur and zinc on Plant Height, Green leaves, Pod per plant, Grain yield per plant and straw yield per 
plant of Black gram. The Journal of Rural and Agricultural Research 14 (1):49-51.

Tahir Muhammad, Sher Alam and Muhammad Majeed Atif Muhammad.
(2014). Effect of molybdenum on yield and quality of black gram (Vigna mungo L.) Pakistan Journal of Life and Social Sciences 12 (2):101-105.

\section{How to cite this article:}

Chhatrapati Mahilane, Vikram Singh and Raisen Pal. 2018. Response of Different Levels of Zinc and Molybdenum on Yield Attribute and Economics of Blackgram (Vigna mungo L.) under Agro-climatic East Uttar Pradesh, India. Int.J.Curr.Microbiol.App.Sci. 7(12): 3120-3125. doi: https://doi.org/10.20546/ijcmas.2018.712.359 